\title{
Promoting Multicultural Competence among EIL Learners
}

\author{
Yulia Hapsari ${ }^{1}$, Ika Puspitasari ${ }^{2}$ \\ \{hapsari.yulia@ub.ac.id ${ }^{1}$, ikapuspitasari@ub.ac.id $\left.{ }^{2}\right\}$ \\ Universitas Brawijaya, Indonesia ${ }^{1,2}$
}

\begin{abstract}
Currently, economy and social factors underlying practices of international trade, tourism, media, and education trends in Asia have grown very rapidly. This condition promotes increasing need of English used as lingua franca in Asia as the expanding circle this needs incur the use and exposure of Asian Englishes it is imperative for educational institutions in Asia to find English instructional strategies which promotes multicultural competence and awareness of the Englishes among their learners. The level of multilingualism and polyglossia in Indonesia add potential danger to the teaching of English if the target outcomes of the learning are to have native-like competence. Therefore, this study proposes some basic principles for the teaching of English to promote multicultural competence and awareness of the Englishes among English learners in Indonesia. There are four basic principles namely (1) re-focusing the practice of the English teaching so that the purpose of English teaching in school is not to pass exams; (2) shifting the English teaching approach from teaching English as a foreign language to teaching English as an international language. Thus, the target outcome of the learning should be to have internationally accepted English; (3) the teaching of grammar should be presented as an integral part of a context that supports the understanding of pragmatic content in a particular context for an effective communication to take place; (4) adopting intercultural language learning pedagogy in the learning process.
\end{abstract}

Keywords: English Grammar, Intercultural, Multicultural, Teaching, World's Englishes

\section{Introduction}

English is blooming in Asia. In 2008 Bolton [1] revealed that more than 800 million people in South, Southeast and East Asia had some knowledge of English. This number is surely increasing at present as economic and social factors shaping the spread of English such as demographic, economic changes and educational trends [2] have been escalating in the region. English is increasingly being introduced as the first "foreign" language taught in Asian schools $[3]$.

The concept of "foreign" language can be derived from Kachru's [4] famous three-circle model of World's Englishes. Kachru [4] identified Englishes based on the historical spread and functional differences of English. There are the Inner Circle (which demands ownership and norm formation), the Outer Circle (where English is a second language, with established local norms from time to time), and the Expanding Circle (in which English is spoken as a foreign language). While expanding circles are thought to depend on inner circle's norms, Seidlhofer [5] exposed that empirical research have reported that multilingual speakers adopt independent norms to achieve clarity. Since "native" speakers as the Inner Circle users are outnumbered by 
the users of both Outer and Expanding circles, and that English gets more attention in the expanding circle than in the inner circle [2][6], the ownership and norm enforcement status of the "native" speakers is questionable [7].

Currently, economy and social factors underlying practices of international trade, tourism, media, and education trends in Asia have grown very rapidly. This condition promotes increasing need of English used as lingua franca in Asia as the expanding circle of Kachru's [4] World's Englishes. These needs incur the use and exposure of Asian Englishes which are usually described with reference to their country of origin. Bruneian English, Malaysian English, Filipino English and Singaporean English are well-known examples. As Asian Englishes are part of the Englishes that has been shaped by the cultural needs of its speakers, there are "subvarieties" within each of Asian Englishes, and these are usually classified on the continuum from formal and educated to informal and colloquial [3]. To cope with the need of English, there is no country in Asia where English is not the first language after the national language [3].

Acknowledging heterogeneity of English(es) as an international language and its function as lingua franca as well as the multicultural and multilingual background of its speakers, it is imperative for educational institutions in Asia to find English instructional strategies which promotes multicultural competence and awareness of the Englishes among their learners. There is inevitably a critical need for perspectives, principles and practices in the teaching of English to a multilingual and multicultural society [8].

\section{Research Method}

With regard to the previously elaborated background, this study aims at proposing some basic principles for the teaching of English to promote multicultural competence and awareness of the Englishes among English learners in Indonesia. Indonesia was chosen because the level of multilingualism and polyglossia in Indonesia is an additional potential danger that focuses on English, which in Indonesia is one of the six subjects registered for the national exam, may lead to a reduced emphasis on the use of Bahasa Indonesia as the national language [3]. To achieve the purpose of the study, review to some related literature was conducted employing the descriptive qualitative approach. According to Creswell [9], qualitative research is an approach in research that is specifically intended to explore and understand the meaning attributed by individuals or groups to social issues. The findings and results of the study were presented descriptively.

\section{Findings and Results}

A heterogeneous global English community with heterogeneous English and different competency modes [7] is an avoidable fact of English, its uses, and its users. The dominant disciplinary constructs based on homogeneity - namely a homogeneous grammar system, a homogeneous speech community, homogeneous competence [7] are being questioned by numerous ELF research. This homogeneity offers less flexibility needed by the heterogeneous users to apply the language serving its fundamental function as a communication tool.

In the real multilingual and multicultural Asian setting, English is fundamentally called for its capacity as a lingua franca. Diverse language and cultural background of Asian people is an invaluable treasure, yet also a stumbling block in English learning and teaching. Although 
Asian people are accustomed to doing code mixing and lexical borrowing from many different languages spoken around them, these multilingual English speakers also regularly need to use English as a lingua franca (ELF) when they communicate with multilingual peers across the region (Kirkpatrick \& Sussex, 2012). What is interesting with using ELF in Asia is that most of the time the parties who use ELF are English as a Foreign Language (EFL) users. Thus, when they are using English as their lingua franca, it is highly possible that their English is affected by their respective native language (L1) and culture. In this sense, the negotiation of meaning between the speakers will impose necessary modification for the communication to take place effectively.

Communication can be understood as 'an activity in which symbolic content is not merely transmitted from one source to another, but exchanged between human agents, who interact within a shared situational and/or discursive context' [10] so that 'there is some predictable relation between the message transmitted and the message received' [11] as cited by Marsen [12]. From this understanding, we can learn that effective communication is based more on the situation or context so that meaning can be predicted and understood by each party involving in the communication. As stated by Canagarajah [7], effective communication is not based on grammar or uniform formal competence, but pragmatic and performance. This statement implies that accurate understanding of grammar which refers to language structure is not the key point of learning a language as a means of communication.

Highlights on grammar teaching and learning that has been given more to language structure should be shifted to pragmatic considerations underlying the emergence of such structure. As grammar is a system of meaningful structures and patterns that are governed by particular pragmatic constraints [13], grammar instruction through context can positively affects learner's competence to use grammatical structures accurately in language skills and help learners to acquire nature of the language which will facilitate their understanding of the language [14]. Such an orientation will help us reconcile ourselves with the reality of English as a heterogeneous language with multiple grammatical systems and norms, accommodating various expressions of local values and identities [3]. Therefore, it is necessary to prepare the teaching of English with a multicultural approach to provide meaningful contexts in addition to accuracy of the sentence structure that is especially needed in written (academic) communication.

Multiculturalism, in Indonesia, is identical with multilingual setting. Indonesia has more than 700 languages, of which more than 150 exceed 10,000 speakers. This "multilingual settings could weaken the sense of nationalism" [3]. Therefore, the position of Bahasa Indonesia as the national language is crucial. Nowadays, in many schools and universities, English is also used as an instructional language coupled with Bahasa Indonesia as the national language. English is also one of mandatory subjects from junior high school to university level. It is learnt by millions of Indonesian students in thousands of Indonesian schools and universities. To top up, Indonesian government also let English to be learnt by young learners based on their personal choice. These practices can be regarded as actions taken by Indonesian government and policy makers in response to the rapid shifting role and function of English in Asia. In this mosaic, with English as the dominant international language, there is a real emphasis that "for an Indonesian learner of English as a lingua franca, the key issue is how to get things across, how to understand and how to be understood; the issue is not primarily native-like" [3].

With regard to the explanation above, the need for English language teaching that has the potential to follow the plurality of grammar, taking into account the multilingual and multicultural backgrounds of Indonesian students is very important. English teaching is no longer synonymous with English in the Anglophone countries. It will be more about teaching 
English as an international language - the lingua franca to global citizens - where a variety of English will be found. To realize this teaching, there are basic principles that need to be taken.

First, evaluating the achievement of the objectives of learning English in schools in Indonesia. Based on the Indonesian 1994 curriculum and competency-based curriculum [15][16], English is needed to study and improve science, technology and arts, as well as to enhance international relations which are expected to encourage Indonesia's development. The achievement of this goal is measured by evaluating the English language skills of educational institutions graduates [17]. This measurement of English proficiency is usually carried out using tests. And this choice of the measurement seems contribute to the misconduct of the English teaching. Teachers and students are starting to focus more on how to pass the tests with flying colors than on how to use English to advance science, technology, arts, and international relations. Needs analysis to gather accurate information about kinds of English(es) required to achieve the goals that lead to the provision of suitable teaching materials and learning strategies is barely done. Schools and students as well as students' parents are in a tight competition to pass the exams with the best score. It is as if the purpose of studying English in school is only to pass exams.

Next, it is time to shift the perspective, from teaching English as a foreign language in Indonesia to teaching English as an international language. That way, inner circle English is no not necessarily to be the one and only reference in the teaching and learning of English. While the World's Englishes models legitimize outer circle variations in their national context, they are now beginning to leak beyond their borders, creating a need for inner-circle speakers as well to negotiate outer-circle variations in day-to-day communication [7]. Therefore, in addition to the more familiar varieties of English spoken in inner circle countries (e.g., the US and UK), other varieties spoken in outer circle (e.g., Singapore and the Philippines) and expanding circle (e.g., China, Indonesia, and Japan) countries [18] also need to be given as an exposure as well as a target language model for students to be able to understand and be understood by English speakers in the world. Alsagoff [8] shows that it is increasingly clear that in order to prepare L2 learners to be effective speakers of English as an International Language (EIL), they need to understand this new variety and be understood by speakers of this variety. Thus, learning outcomes should no longer be like native speakers, but should shift to having "internationally accepted English".

Furthermore, the provision of Englishes will surely incur consequences. One of which is the possibility for the Englishes to tag along un-uniformity of grammar. Since English has been shaped by the cultural needs of its speakers [3], we must consider how effective communication can be based not on uniform grammar or formal competence, but on pragmatics and performance [7]. Hence, it can be learned that the teaching of grammar should no longer be presented explicitly through isolated sentences topped up with drilling and substitution. Instead, grammar should be presented as an integral part of the context that supports the understanding of pragmatic content in a particular context. Helena [19] argued that teaching grammar does not always mean teaching the forms but also teaching the meaning and function of grammar. This perspective is important because commercially available grammar books tend to mix the structural and functional labels of grammar in one sentence pattern causing confusion among Asian students.

Finally, instructional strategies in the teaching of English grammar must be highlighted. Scarino and Liddicoat [20] suggested principles that can be used as starting points for the development of pedagogy in Intercultural Language Learning (IcLL). Pedagogy of IcLL is a situation where pedagogy language learning reflects post-structuralist influences [21], thus, the identity of language learners is interpreted as something that is plural and diverse, and that 
language and culture depend on the interlocutors [22][23]. This is a continuation of the second language acquisition concept put forward by Peirce [24] where language learners as entities have complex social identities, and language is a reflection of these identities as well as a medium to reshape their identities. The IcLL pedagogy is conceptualized as a cycle of process of four activities namely noticing, comparing, reflecting, and interacting.

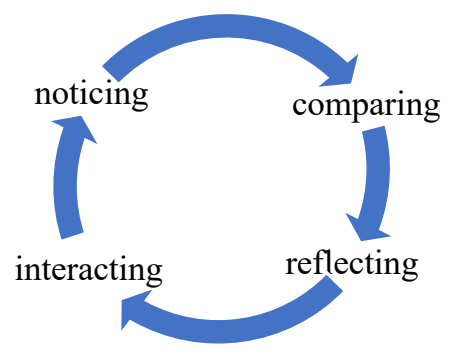

Fig. 1. Interaction process in IcLL [20].

The activity of noticing in IcLL is important for learners because they are directed to be able to capture the cultural similarities and differences contained in speech in the target language as this is what they will really need when they use the target language outside the classroom.

The aim of the process of comparing is to make the learners are able not to compare the similarities and differences between the target culture and the learners' own culture, but more to measure the learners' knowledge about the target culture and how deep their understanding of the knowledge is. This activity leads to the subsequent activity, namely reflecting.

Reflecting is the core of intercultural competence [25]. In this process, learners are invited to interpret the differences in diverse cultures that they encounter through utterances in the target language or activities or attitudes carried out by people who use the target language. This activity involves a process of reflection to see how the learners think, feel, and react in dealing with cultural differences. This will lead to how learners should engage themselves constructively towards this diversity.

The final step is interaction. Putting all the knowledge and experiences that have been learned from the previous three activities, learners are expected to be able to interact appropriately with people who come from different language and cultural backgrounds. This interaction is intended to get the meaning / values from the experience so that they can derive, explore, and internalize these values to find the best ways in responding to others with different language and culture.

\section{Conclusion}

The previous discussion has led to the notion that the teaching of grammar needs to be reevaluated and improved by considering the inclusion of multiculturalism into it. It somehow takes several consequences in so doing. Grammar is no longer suggested to be offered as an isolated course for students. Instead, it should be taught integrated in multicultural contexts to ensure that the pragmatic comprehension is achievable. The knowledge of grammar should instead help learners to use English lingua franca. It indicates that native-like language is no longer highly up-held as learners should be directed to master internationally-accepted English. 
That is when world Englishes come into existence. It is the English which brings with it the conception of multiculturalism.

\section{Acknowledgements}

The acknowledgement is made to Faculty of Cultural Studies Universitas Brawijaya and the ISCS committee for the publication of this paper.

\section{References}

[1] K. Bolton, "English in Asia, Asian Englishes, and the issue of proficiency," English Today, vol. 24, no. 2, p. 3, 2008.

[2] D. Graddol, English next, vol. 62. British Council London, 2006.

[3] A. Kirkpatrick, "English in ASEAN: Implications for regional multilingualism," J. Multiling. Multicult. Dev., vol. 33, no. 4, pp. 331-344, 2012.

[4] B. B. Kachru, The alchemy of English: The spread, functions, and models of non-native Englishes. University of Illinois Press, 1986.

[5] B. Seidlhofer, "English as a lingua franca," Oxford, 2005.

[6] D. Crystal, English as a global language. Ernst Klett Sprachen, 2003.

[7] A. S. Canagarajah, "Negotiating the local in English as a lingua franca," Annu. Rev. Appl. Linguist., vol. 26, p. 197, 2006.

[8] L. Alsagoff, S. L. McKay, G. Hu, and W. A. Renandya, Principles and practices for teaching English as an international language. Routledge, 2012.

[9] J. W. Creswell and J. D. Creswell, Research design: Qualitative, quantitative, and mixed methods approaches. Sage publications, 2017.

[10] J. Price, "Using complexity theory to understand what's happening to technical communication," in Proceedings of IPCC 97. Communication, 1997, pp. 17-27.

[11] D. A. Graber, "The rocky road to new paradigms: Modernizing news and citizenship standards," Polit. Commun., vol. 20, no. 2, pp. 145-148, 2003.

[12] S. Marsen, Communication studies. Macmillan International Higher Education, 2006.

[13] D. Larsen-Freeman, "Teaching grammar," Teach. English as a Second or foreign Lang., vol. 3, pp. 251-266, 2001.

[14] Ç. T. Mart, "Teaching grammar in context: why and how?," Theory Pract. Lang. Stud., vol. 3, no. $1,2013$.

[15] Departemen Pendidikan dan Kebudayaan, Kirikulum Sekolah Menengah Umum: Landasan, Program dan Pengembangan. Jakarta: Depertemen Pendidikan dan Kebudayaan, 1993.

[16] Departemen Pendidikan Nasional, Kurikulum erbasis Kompetensi: Mata Pelajaran Bahasa Inggris Sekolah Menengah Umum (Buram). Jakarta: Departemen pendidikan Nasional, 2001.

[17] A. Saukah, "Pengajaran bahasa Inggris di Indonesia: Tinjauan terhadap unjuk kerja pembelajar serta upaya peningkatannya," Malang, Indones. Dep. Pendiddikan Nasional-Universitas Negeri Malang, 2003.

[18] W. A. Renandya and H. P. Widodo, "English Language Teaching Today: An Introduction," in English Language Teaching Today, Springer, 2016, pp. 3-11.

[19] H. I. R. Agustien, "Teaching English grammar in Asian contexts," in English Language Teaching Today, Springer, 2016, pp. 209-226.

[20] A. Scarino and A. Liddicoat, Teaching and learning languages: A guide. Curriculum Corporation Melbourne, 2009.

[21] A. Welsh, "Avoiding stereotyping and enhancing intercultural understanding," Teflin J., vol. 22, no. 1, pp. 34-44, 2011.

[22] C. Crozet and A. J. Liddicoat, "The challenge of intercultural language teaching: Engaging with 
culture in the classroom," Striving third place Intercult. competence through Lang. Educ., pp. $113-125,1999$.

[23] J. Lo Bianco and C. Crozet, Teaching Invisible Culture: Classroom Practice and Theory. ERIC, 2003.

[24] B. N. Peirce, "Social identity, investment, and language learning," TESOL Q., vol. 29, no. 1, pp. 9-31, 1995.

[25] V. Kohonen, "Student reflection in portfolio assessment: making language learning more visible," Babylonia, vol. 1, no. 2000, pp. 13-16, 2000. 